\title{
Perbedaan Status Pemberian ASI Eksklusif terhadap Perubahan Panjang Badan Bayi Neonatus
}

\section{The Differences of Exclusive Breastfeeding for Neonates Length}

\author{
Ade Devriany", Zenderi Wardani, Yunihar \\ Poltekkes Kemenkes Pangkalpinang \\ (*adevriany@yahoo.com)
}

\begin{abstract}
ABSTRAK
Air Susu Ibu (ASI) eksklusif merupakan makanan alamiah yang pertama dan utama bagi bayi yang lahir karena ASI dapat memenuhi kebutuhan bayi akan energi dan zat gizi bayi di masa pertumbuhan selama 6 bulan pertama kehidupannya. Kementerian Kesehatan pada tahun 2015 menargetkan cakupan ASI eksklusif sebesar 80\%. Namun, cakupan ASI eksklusif di Kepulauan Bangka Belitung masih cukup rendah yaitu (59,4\%) di wilayah Kota Pangkalpinang. Penelitian ini bertujuan untuk menilai perbedaan antara status pemberian ASI eksklusif terhadap perubahan panjang badan bayi neonatus di RSUD Depati Hamzah Pangkalpinang. Desain penelitian adalah penelitian cohort dengan jumlah sampel 34 orang ibu yang melahirkan di RSUD Depati Hamzah Pangkalpinang pada bulan Juni-Juli 2015. Instrumen penelitian yang digunakan adalah kuesioner dan pengukur tinggi badan bayi. Uji t-independent digunakan untuk melihat perbedaan hasil pengukuran panjang badan bayi neonatus pada masing-masing kelompok observasi setiap 7 hari berturut-turut selama 28 hari. Hasil penelitian menunjukan bahwa kelompok ASI non eksklusif sebesar 55,9\% (19 orang), sedangkan ASI eksklusif sebesar 44,1\% (15 orang). Rata-rata perubahan panjang badan neonatus yang diberikan ASI eksklusif selama 1 bulan lebih besar yaitu 10,87 $\mathrm{cm}$ dibandingkan ASI non eksklusif yang hanya $8,53 \mathrm{~cm}$. Hasil ini menunjukan ada perbedaan rata-rata perubahan panjang badan antara neonatus yang diberikan ASI eksklusif dan neonatus yang diberikan ASI non eksklusif.
\end{abstract}

Kata kunci : ASI eksklusif, neonatus, panjang badan

\section{ABSTRACT}

Exclusive breastfeeding is the first and foremost of natural food for baby because breastfeeding can fulfill the baby's needs for energy and nutrients the baby even during the first 6 months of life.The Ministry of Health in 2015 targets for exclusive breastfeeding 80\%. In 2013, the highest coverage of exclusive breastfeeding in Bangka Belitung is Pangkalpinang (59,4\%)So this study aimed to assess the difference between the status of exclusive breastfeeding to changes the body lenght of neonates in RSUD Depati Hamzah Pangkalpinang. This type of research was a cohort with a sampel of 34 mothers who gave birth in RSUD Depati Hamzah Pangkalpinang in June-July 2015. The research instrument used a questionnaire and length board scaleThe independent t-test aimed to see the difference in weight and measurement results body lenght of neonates in each group observation status every 7 consecutive days as long 28 day. The results showed that mothers who non exclusive breastfeeding is 55,9\% (19 people) and exclusive breastfeeding is 44,1\% (15 people). The average of lenght neonates given exclusive breastfeeding 1 month is greater was 10,87 cm than non exclusive breastfeeding only was 8,53 cm.The results showed that there was no difference significanthy of mean in lenght between exclusive breastfeeding and non exclusive breastfeeding.

Keywords : Exclusive breastfeeding, neonates, weight \& lenght 


\section{PENDAHULUAN}

Neonatus adalah bayi baru lahir sampai berusia empat minggu yang masih rentan dalam menyempurnakan berbagai penyesuaian fisiologis dan biokimia. ${ }^{1}$ Neonatus disebut juga dengan Bayi Baru Lahir (BBL) merupakan individu yang sedang bertumbuh dan harus dapat melakukan penyesuaian diri dari kehidupan intrauterin ke kehidupan ekstrauterin. ${ }^{2}$ Hari pertama kelahiran sangat penting, banyak perubahan yang terjadi pada bayi dalam menyesuaikan diri dari kehidupan di dalam rahim ke kehidupan di luar rahim

Dalam rangka menurunkan angka kesakitan dan kematian anak, Word Health Organization (WHO) merekomendasikan bahwa bayi yang berumur 0-6 bulan hanya memerlukan ASI saja tanpa cairan atau makanan padat apapun yang disebut dengan ASI eksklusif. Sesudah umur 6 bulan, bayi baru dapat diberikan makanan pendamping ASI (MP-ASI) dan ibu tetap memberikan ASI sampai anak berumur minimal 2 tahun. Penegasan pemberian ASI eksklusif juga diatur dalam PP Nomor 33 tahun 2012 Pasal 6 yang berbunyi setiap ibu yang melahirkan harus memberikan ASI eksklusif kepada bayi yang dilahirkannya. ${ }^{3}$

Banyak penelitian yang telah membuktikan bahwa ASI penting untuk tumbuh kembang optimal bayi. Salah satu jurnal yang melakukan penelitian tersebut adalah penelitian dari Sofyana yang menyatakan bahwa rata-rata perubahan panjang badan neonatus selama 1 bulan (28 hari) pada neonatus yang diberikan ASI eksklusif sebesar 1,078 $\mathrm{cm}$, sedangkan neonatus yang diberikan non eksklusif sebesar 1,008 cm. ${ }^{1}$ Lebih lanjut hasil penelitian menunjukkan bahwa pada balita baduta usia 6-24 bulan yang tidak ASI eksklusif lebih banyak mengalami stunting sebesar 30,7\%, dibandingkan dengan balita baduta yang mendapatkan ASI eksklusif hanya $11,1 \%$ stunting. ${ }^{4}$ Sebaliknya bayi yang mendapat ASI eksklusif lebih banyak yang mempunyai status gizi $(\mathrm{TB} / \mathrm{U})$ normal $(88,9 \%)$ dibandingkan balita baduta yang tidak eksklusif $(69,3 \%) .{ }^{4}$ Hasil ini menunjukkan ada kecenderungan balita yang tidak diberi ASI eksklusif lebih tinggi proporsi stunting. Lebih lanjut hasil penelitian Susanty mendukung bahwa lama menyusui, berhubungan signifikan dengan kejadian gizi bu$\operatorname{ruk}(\mathrm{p}=0,037$ dan $\mathrm{OR}=3,05) .{ }^{5}$

Word Health Organization (WHO) dan
United Nation Childrens'Fund (UNICEF) pada tahun 2009 menargetkan pemberian ASI di Asia sebesar 55\%, sedangkan di Indonesia bayi yang menyusui ASI sampai 6 bulan hanya sebesar 35\%. ${ }^{6}$ Selain itu, Kementerian Kesehatan Republik Indonesia pada tahun 2015 menargetkan untuk para ibu harus menyusui bayinya secara eksklusif sebesar $80 \% .^{7}$ Namun, dibandingkan dengan target yang ditetapkan oleh Kementerian Kesehatan Republik Indonesia, bayi yang diberi ASI eksklusif sampai 6 bulan di Indonesia masih sangat rendah (35\%).

Berdasarkan data dari Profil Kesehatan Indonesia, cakupan pemberian ASI eksklusif pada bayi 0-6 bulan di Indonesia pada tahun 2013 sebesar $54,3 \%$, sedikit meningkat apabila dibandingkan dengan tahun 2012 yaitu sebesar 48,6\%. Provinsi dengan cakupan pemberian ASI eksklusif pada bayi 0-6 bulan tertinggi terdapat di Nusa Tenggara Barat sebesar 79,74\%, diikuti oleh Sumatera Selatan sebesar 74,49\%, dan Nusa Tenggara Timur sebesar 74,37\%. Sedangkan cakupan pemberian ASI eksklusif terendah terdapat di Provinsi Maluku sebesar 25,21\%, diikuti oleh Jawa Barat sebesar $33,65 \%$ dan Sulawesi Utara sebesar 34,67\% serta untuk Provinsi Kepulauan Bangka Belitung urutan 14 terendah cakupan pemberian ASI-nya yaitu sebesar $59,41 \%{ }^{8}$

Berdasarkan data dari Profil Kesehatan Kepulauan Bangka Belitung 2013, cakupan pemberian ASI eksklusif di Kepulauan Bangka Belitung sebesar $46,7 \%$. Nilai ini masih tergolong di bawah target yang ditetapkan oleh Kementerian Kesehatan Republik Indonesia yaitu 80\%. Pada tahun 2013, dengan cakupan tertinggi pemberian ASI eksklusif yaitu pada Kota Pangkalpinang sebesar 59,4\% dan terendah pada Kabupaten Bangka dan Bangka Barat yaitu 34,9\%. ${ }^{9}$ Tujuan penelitian ini adalah untuk menilai perbedaan antara status pemberian ASI eksklusif dan non eksklusif terhadap perubahan panjang badan bayi neonatus di RSUD Depati Hamzah kota Pangkalpinang.

\section{BAHAN DAN METODE}

Jenis penelitian yang digunakan adalah metode penelitian survei analitik dengan rancangan penelitian cohort. Rancangan cohort ini mempelajari dinamika kolerasi antara status pemberian ASI eksklusif dan non eksklusif terhadap perubahan berat badan dan panjang badan 
bayi neonatus melalui pendekatan longitudinal. ${ }^{10}$ Penelitian ini dilakukan di RSUD Depati Hamzah Kota Pangkalpinang yang merupakan Rumah Sakit Umum Daerah (RSUD) yang mencapai target pemberian ASI eksklusif oleh Kementerian Kesehatan RI yaitu sebesar $80 \%$. Penelitian ini dilakukan pada bulan Juni sampai dengan bulan Agustus 2015. Populasi dalam penelitian ini adalah bayi yang lahir di RSUD Depati Hamzah Pangkalpinang periode bulan Juni-Juli 2015. Populasi dalam penelitian ini adalah bayi yang lahir di RSUD Depati Hamzah kota Pangkalpinang periode bulan Juni-Juli 2015. Sampel adalah sebagian yang diambil dari keseluruhan subjek yang diteliti dan dianggap mewakili seluruh populasi. ${ }^{10}$ Sampel dalam penelitian ini berjumlah 34 orang yang dipilih secara purposive sampling dan sesuai dengan kriteria inklusi bersedia menjadi responden dan bertempat tinggal di wilayah Kota Pangkalpinang. Instrumen yang digunakan dalam penelitian ini adalah kuesioner, lembar observasi dan infantometer. Teknik pengumpulan data penelitian dimulai dari mengidentifikasi status pemberian ASI eksklusif dan non eksklusif, kemudian diikuti secara prospektif perubahan panjang badan pada bayi neonatus. Teknik analisis dilakukan secara univariat untuk mengetahui karakteristik umur ibu dan bayi, jenis kelamin bayi, status pemberian ASI yang diberikan kepada bayi neonatus, serta perubahan panjang badan bayi neonatus. Analisa juga dilakukan secara bivariat dengan menggunakan uji t-independent karena data terdistribusi normal.

\section{HASIL}

Responden dalam penelitian ini adalah bayi neonatus yang lahir di RSUD Depati Hamzah Kota Pangkalpinang sebanyak 34 orang. Berdasarkan pada Tabel 1 sebagian besar usia ibu berada pada rentang 25-29 tahun, yaitu 44,1\%. Tingkat pendidikan ibu sebagian besar berpendidikan SMA, yaitu sebanyak $55,9 \%$ dengan status pekerjaan ibu yang paling banyak tidak bekerja yaitu sebesar $91,2 \%$, sedangkan berdasarkan jenis persalinannya, lebih banyak ibu responden melakukan operasi sectio, yaitu sebanyak 58,8\% (20 orang).

Tabel 2 menunjukkan status pemberian ASI sebagian besar bayi neonatus diberikan ASI non eksklusif sebanyak 55,9\% (19 orang) dan semua ibu ternyata tidak melakukan IMD kepada bayi
Tabel 1. Karakteristik Responden

\begin{tabular}{lcc}
\hline \multicolumn{1}{c}{ Karakteristik } & $\mathbf{n}$ & $\mathbf{\%}$ \\
\hline Tingkat usia & & \\
$\leq 19$ & 1 & 2,9 \\
$20-24$ & 11 & 32,4 \\
$25-29$ & 15 & 44,1 \\
$30-34$ & 5 & 14,7 \\
$\geq 35$ & 2 & 5,9 \\
Tingkat Pendidikan & & \\
$\quad$ Tidak Sekolah & 1 & 2,9 \\
$\quad$ Tamat SD & 3 & 8,8 \\
Tamat SMP & 5 & 14,7 \\
$\quad$ Tamat SMA & 19 & 55,9 \\
$\quad$ Tamat PT & 6 & 17,6 \\
Status Pekerjaan & & \\
$\quad$ Tidak Bekerja & 31 & 91,2 \\
$\quad$ Bekerja & 3 & 8,8 \\
Jenis Persalinan & & \\
$\quad$ Spontan/normal & 14 & 41,2 \\
$\quad$ Sectio caesar & 20 & 58,8 \\
Melakukan IMD & 0 & 0 \\
$\quad$ Tidak Melakukan IMD & 34 & 100 \\
$\quad$ Melakukan IMD & 0 & 0 \\
Status Pemberian ASI & & \\
$\quad$ ASI Eksklusif & 15 & 44,1 \\
ASI Non Eksklusif & 19 & 55,9 \\
\hline
\end{tabular}

neonatus. Hasil pengukuran panjang badan pada bayi neonatus diperoleh nilai median peningkatan panjang badan terbesar terjadi pada hari ke-28 yaitu sebesar $3,00 \mathrm{~cm}(\mathrm{IQR}=1 \mathrm{~cm})$ dengan perubahan terendah $1 \mathrm{~cm}$ dan perubahan tertinggi $4 \mathrm{~cm}$. Total selisih perubahan panjang badan selama $0-28$ hari yang terjadi pada seluruh responden adalah sebesar 9,56 cm $(\mathrm{SD}=2,710 \mathrm{~cm})$.

Rata-rata perubahan ukuran panjang badan bayi neonatus yang mendapatkan ASI eksklusif dan ASI non-eksklusif pada akhirnya sama $(3,00$ $\mathrm{cm})$ selama 0-28 hari antara kelompok bayi neonatus yang diberikan ASI eksklusif dan ASI non eksklusif, tetapi pada kelompok bayi neonatus yang diberikan ASI eksklusif perubahan panjang badannya lebih cepat meningkat yaitu pada hari ke-14 $(3,00 \mathrm{~cm})$, sedangkan perubahan panjang badan bayi neonatus yang diberikan ASI non eksklusif perubahan panjang badannya terlambat yaitu pada hari ke-28 $(3,00 \mathrm{~cm})$.

Tabel 2 diketahui rata-rata panjang badan kelompok bayi neonatus yang diberikan ASI eksklusif sebesar 10,87 cm (SD=1,959 cm), sedangkan kelompok bayi neonatus yang diberikan ASI 
Tabel 2. Distribusi Perubahan Ukuran Antropometri Panjang Badan (cm)Bayi Neonatus Setiap Minggu Secara Berturut-Turut

\begin{tabular}{lcccccc}
\hline \multicolumn{1}{c}{ Variabel } & Median & Mean & IQR & Std. Deviasi & Minimal-Maksimal & $\mathbf{9 5 \% C I}$ \\
\hline Usia Neonatus & & & & & & \\
Hari ke-7 & 2,00 & & 1 & & $0-4$ & $1,86-2,49$ \\
Hari ke-14 & 2,00 & & 1 & & $1-4$ & $2,07-2,69$ \\
Hari ke-21 & 2,50 & & 1 & & $1-4$ & $2,09-2,85$ \\
Hari ke-28 & 3,00 & 9,56 & 1 & 2,710 & $1-4$ & $2,27-2,96$ \\
$0-28$ hari & & & & & $3-14$ & $8,61-10,50$ \\
\hline
\end{tabular}

Tabel 3. Rata-Rata Perubahan Ukuran Panjang Badan (cm) Bayi Neonatus Setiap Minggu Secara Berturut-Turut Berdasarkan Status Pemberian ASI yang Diberikan Kepada Neonatus

\begin{tabular}{lccccc}
\hline \multirow{2}{*}{ Variabel } & \multicolumn{5}{c}{ Rata-rata Perubahan Panjang Badan (cm) } \\
\cline { 2 - 6 } & $\mathbf{7 ~ h a r i}$ & $\mathbf{1 4}$ hari & $\mathbf{2 1}$ hari & $\mathbf{2 8}$ hari & $\mathbf{0 - 2 8}$ hari \\
\hline Status Pemberian & & & & & \\
ASI Eksklusif & 2,00 & 3,00 & 3,00 & 3,00 & 12,00 \\
ASI Non Eksklusif & 2,00 & 2,00 & 2,00 & 3,00 & 8,53 \\
\hline
\end{tabular}

Tabel 4. Analisis Perbedaan Rata-Rata Panjang Badan (cm) Bayi Neonatus Selama 28 hari Berdasarkan Status Pemberian ASI

\begin{tabular}{lcccc}
\hline \multicolumn{1}{c}{ Variabel } & n & Mean & SD & p value \\
\hline Status Pemberian & & & & \\
ASI Eksklusif & 15 & 10,87 & 1,959 & 0,010 \\
ASI Non Eksklusif & 19 & 8,53 & 2,816 & \\
\hline
\end{tabular}

non eksklusif adalah $8,53 \mathrm{~cm}(2,816 \mathrm{~cm})$. Hasil uji $t$-independent perbedaan status pemberian ASI eksklusif dan ASI non eksklusif terhadap perubahan panjang badan diperoleh nilai $p=0,010$. Hasil uji statistik menunjukan ada perbedaan yang bermakna antara rata-rata perubahan panjang badan kelompok bayi neonatus yang diberikan ASI eksklusif dan kelompok bayi neonatus yang diberikan ASI non eksklusif.

Hasil penelitian menunjukkan bahwa kelompok neonatus yang diberikan ASI eksklusif dan ASI non eksklusif mencapai rata-rata panjang badan yang sama pada minggu keempat sebesar $3 \mathrm{~cm}$. Namun, terlihat bahwa perubahan panjang badannya lebih cepat meningkat pada kelompok neonatus yang diberikan ASI eksklusif yaitu pada hari ke-14 $(3,00 \mathrm{~cm})$, sedangkan perubahan panjang badan neonatus yang diberikan ASI non eksklusif lebih lambat yaitu pada hari ke-28 $(3,00 \mathrm{~cm})$ (Tabel 3).

Tabel 4 menunjukkan bahwa ada perbedaan yang bermakna secara statistik antara rata-rata perubahan panjang badan kelompok neonatus yang diberikan ASI eksklusif dan kelompok neonatus yang diberikan ASI non eksklusif $\mathrm{p}=0,010(\mathrm{p}<0,05)$. Rata-rata panjang badan kelompok bayi neonatus yang diberikan ASI eksklusif lebih besar 10,87 $\mathrm{cm}$ dibandingkan dengan kelompok bayi neonatus yang diberikan ASI non eksklusif $8,53 \mathrm{~cm}$.

\section{PEMBAHASAN}

Air Susu Ibu atau yang dikenal selama ini dengan singkatan ASI merupakan makanan alamiah yang pertama dan paling utama bagi bayi yang lahir karena ASI dapat memenuhi kebutuhan bayi akan energi dan zat gizi bayi bahkan selama 4-6 bulan pertama kehidupannya. ${ }^{11}$ Pemberian ASI dibagi menjadi dua, yaitu ASI eksklusif dan ASI non eksklusif. Menurut World Health Organization (WHO) ASI eksklusif adalah pemberian ASI saja tanpa tambahan cairan lain baik susu formula, air putih, air jeruk, ataupun makanan tambahan lain. Sebelum mencapai usia 6 bulan sistem pencernaan bayi belum mampu berfungsi dengan sempurna, sehingga bayi belum mampu mencerna makanan selain ASI. ${ }^{12}$ 
Air Susu Ibu (ASI) non eksklusif merupakan pemberian ASI yang ditambah dengan makanan lain baik berupa MP-ASI (Makanan Pendamping-Air Susu Ibu) maupun susu formula sebelum bayi berusia 6 bulan. Hasil penelitian ini menunjukkan bahwa sebagian besar bayi neonatus yang mendapatkan ASI non eksklusif lebih banyak dibandingkan dengan bayi neonatus yang mendapatkan ASI eksklusif. Salah satu penyebab banyaknya pemberian ASI non eksklusif pada bayi neonatus, yaitu banyaknya ibu yang melakukan persalinan melalui operasi sectio caesar di RSUD Depati Hamzah Kota Pangkalpinang sebanyak $58,8 \%$ (20 orang). Gagalnya pemberian ASI eksklusif terjadi karena berbagai faktor yaitu adanya pemisahan ibu dan bayi, ketidaknyamanan dan nyeri setelah operasi, ibu sering mengeluh kelelahan sehingga membutuhkan waktu lebih ekstra untuk memulihkan diri sebelum mampu untuk menggendong dan menyusui bayinya. Ketidaknyamanan, nyeri dan kelelahan merupakan kondisi psikis setelah persalinan. Produksi ASI juga sangat dipengaruhi oleh kondisi psikis tersebut sehingga ibu akhirnya bisa tidak berhasil menyusui dengan baik. ${ }^{13}$ Hal ini juga sejalan dengan penelitian Hasianah yang menyatakan bahwa sectio caesar menurunkan keberhasilan ASI eksklusif secara sangat signifikan. ${ }^{14}$

Selain operasi sectio caesar, Inisiasi Menyusui Dini (IMD) juga memiliki pengaruh nyata terhadap pelaksanaan ASI eksklusif. Hasil penelitian Fikawati menyatakan bahwa informan dengan fasilitasi IMD berpeluang lebih besar memberikan ASI eksklusif. Hal ini dikarenakan refleks isap bayi paling kuat terjadi pada 30 menit pertama setelah dilahirkan. Isapan bayi pada puting ibu akan merangsang pengeluaran hormon prolaktin (yang merangsang produksi ASI) dan hormon oksitosin (yang merangsang pengeluaran ASI). Kerja kedua hormon tersebut akan membuat kolostrum lebih cepat keluar. ${ }^{15}$ Segala yang dilakukan bayi diatas dada dan perut ibu, seperti menyentuh, mengisap, dan menjilat dada maupun puting susu, akan merangsang pelepasan hormon oksitosin yang berperan penting dalam refleks pengeluaran ASI. Saat bayi berhasil menyusu dini, ini akan mempengaruhi keberhasilannya dalam menyusu secara ASI eksklusif berikutnya. ${ }^{16}$

Penelitian Juliastuti menyatakan bahwa ibu yang melaksanakan IMD memiliki kemungkinan untuk memberikan ASI eksklusif 5,3 kali lebih besar dari pada ibu yang tidak melaksanakan inisiasi menyusui dini dan hubungan keduanya secara statistik signifikan $(p=0,002) .{ }^{17}$ Hal ini sejalan dengan penelitian yang kami lakukan, bahwa tidak adanya ibu bersalin yang melakukan parktik IMD memberikan kontribusi terhadap rendahnya bayi nenonatus yang diberikan ASI ekskulif.

Bayi neonatus yang mendapat ASI eksklusif sebesar 44,1\% dan hal ini dapat dikaitkan dengan tingkat pendidikan ibu yang sebesar $55,9 \%$ adalah tamat SMA. Selain pelaksanaan IMD yang dapat menyebabkan keberhasilan praktik pemberian ASI, tingkat pendidikan ibu juga dapat menjadi faktor pemicu keberhasilan pemberian ASI eksklusif. Penyebab keberhasilan dan kegagalan praktik pemberian ASI eksklusif dapat dipengaruhi oleh beberapa faktor yaitu pendidikan, pengetahuan, dan pengalaman ibu adalah faktor predisposisi yang berpengaruh positif terhadap keberhasilan ASI eksklusif, sedangkan IMD adalah faktor pemungkin yang kuat terhadap keberhasilan ASI eksklusif. ${ }^{15}$

Antropometri gizi berhubungan dengan berbagai macam pengukuran dimensi tubuh dan komposisi tubuh dari berbagai tingkat umur dan tingkat gizi. Berbagai jenis ukuran tubuh, antara lain berat badan, tinggi badan, lingkar lengan atas dan tebal lemak dibawah kulit. ${ }^{18}$ Antropometri gizi yang digunakan pada penelitian ini adalah panjang badan karena perubahan panjang badan bayi neonatus termasuk stabil selama 28 hari.

Bayi yang mendapatkan ASI umunya tumbuh dengan cepat pada 2-3 bulan pertama kehidupannya, tetapi lebih lambat dibandingkan bayi yang tidak mendapat ASI eksklusif. Dalam minggu pertama kehidupan, sering ditemukan penurunan berat badan sebesar $5 \%$ pada bayi yang mendapat susu formula, dan $7 \%$ pada bayi yang mendapat ASI. Apabila terjadi masalah dalam pemberian ASI penurunan berat badan sebesar 7\% dapat terjadi pada 72 jam pertama kehidupan. Selain pengukuran antropometri berat badan, perubahan panjang badan juga dapat diukur selama 28 hari pada bayi neonatus. ${ }^{19}$

Pengukuran perubahan panjang badan yang paling besar terjadi pada minggu keempat yaitu dengan nilai median sebesar $3 \mathrm{~cm}$. Penelitian 
ini tidak sejalan dengan penelitian Sofyana bahwa rata-rata peningkatan panjang badan terbesar terjadi pada minggu kedua yaitu sebesar 0,334 $\mathrm{cm}(\mathrm{SD}=0,1708 \mathrm{~cm})$. Adapun total rata-rata perubahan panjang badan selama 28 hari yang terjadi pada seluruh responden adalah sebesar $1,050 \mathrm{~cm}$ $(\mathrm{SD}=0,2546 \mathrm{~cm}){ }^{1}$

Pengukuran panjang badan digunakan untuk menilai status perbaikan gizi. Selain itu, panjang badan merupakan indikator yang tepat untuk melihat pertumbuhan fisik masa lampau (stunting). ${ }^{20}$ Penelitian Anugraheni menyatakan bahwa panjang badan lahir rendah $(\mathrm{p}=0,000 ; \mathrm{OR}=2,81)$ merupakan faktor risiko kejadian stunting pada anak usia 12-36 bulan di Kecamatan Pati, Kabupaten Pati. ${ }^{21}$ Penelitian ini sejalan dengan penelitian Rahayu dan Sofyaningsih bahwa adanya hubungan yang signifikan antara panjang badan lahir rendah dengan kejadian stunting pada usia 6-12 bulan $(\mathrm{p}=0,001)$, tetapi tidak menunjukkan hubungan yang signifikan dengan kejadian stunting pada usia 3-4 tahun. ${ }^{22}$

Air Susu Ibu (ASI) merupakan makanan utama bagi bayi sehingga dapat mencapai tumbuh kembang yang optimal. Pemantauan pertumbuhan bayi dapat dilakukan dengan menimbang berat badan, serta mengukur panjang badan dan lingkar kepala bayi. Hasil penelitian ini menunjukkan bahwa ada perbedaan yang bermakna secara statistik antara rata-rata perubahan panjang badan kelompok neonatus yang diberikan ASI eksklusif dan kelompok neonatus yang diberikan ASI non eksklusif.

Hasil penelitian ini sejalan dengan penelitian Ariani yang bertujuan untuk melihat kecepatan pertumbuhan bayi prematur yang mendapatkan nutrisi ASI, PASI dan ASI ditambahkan PASI. Hasil pengukuran panjang badan bayi bermakna secara statistik pada ketiga kelompok $(p<0,000){ }^{23}$ Panjang badan bayi dengan nutrisi ASI yang diukur setelah bayi keluar dari Rumah Sakit sebesar $47,66 \mathrm{~cm}$. Panjang badan bayi prematur dengan nutrisi ASI ini lebih tinggi dibandingkan dengan bayi prematur yang diberikan PASI $(44,88 \mathrm{~cm})$ maupun diberikan ASI dan PASI sekaligus (44,65 $\mathrm{cm}){ }^{23}$ Panjang badan mencerminkan pola makan dan kesehatan anak. Pola pemberian makan pada bayi, akan mempengaruhi panjang tungkai yang merupakan komponen utama panjang badan. Ke- tika bayi, pertumbuhan tungkai bawah lebih cepat dibanding bagian tubuh lainnya sehingga penting untuk memberikan nutrisi terbaik anak sejak bayi. Berdasarkan hasil penelitian Susiloretni, dkk menyatakan bahwa pertambahan tinggi badan lebih panjang terjadi pada bayi 0-2 bulan di Puskesmas Guntur 1 (kelompok intervensi) dengan selisih $1,15 \mathrm{~cm}$ lebih panjang dibandingkan dengan bayi 6-24 bulan di Puskesmas Gajah (kelompok kontrol) dengan selisih $0,006 \mathrm{~cm}^{24}$

Beberapa hasil penelitian menunjukkan, anak yang mendapat ASI pada masa bayinya secara bermakna lebih tinggi dibanding anak yang mendapat susu formula. Berdasarkan hasil penelitian Lony ${ }^{25}$, perubahan panjang bayi neonatus yang diberikan ASI eksklusif sebesar $58,2 \mathrm{~cm}$ sedangkan bayi yang mendapatkan ASI non eksklusif $54,8 \mathrm{~cm}$. Rata-rata panjang badan bayi yang hanya mendapatkan nutrisi ASI eksklusif sebesar $66,179 \mathrm{~cm}$ dan yang mendapatkan ASI non eksklusif sebesar 65,871. Bayi yang disusui dalam waktu yang lebih lama, akan memperoleh semua kandungan zat gizi ASI. Jika pada masa tersebut bayi memperoleh asupan gizi yang sesuai, maka pertumbuhan dan perkembangannya akan optimal. Hasil tersebut didukung oleh penelitian Amanda ${ }^{26}$, bahwa terdapat hubungan pada lamanya menyusui dengan status gizi anak usia $<2$ tahun berdasarkan indikator $\mathrm{BB} / \mathrm{U}$ dan $\mathrm{TB} / \mathrm{U}$.

Namun demikian, berbeda dengan hasil penelitian Sofyana ${ }^{1}$ yang menyatakan tidak terdapat perbedaan yang signifikan pada dampak pemberian nutrisi ASI eksklusif dan non eksklusif terhadap perubahan rata-rata ukuran panjang badan neonatus yang dirawat di RSUD Al Ihsan Provinsi Jawa Barat, yaitu neonatus yang diberikan ASI eksklusif menunjukkan perubahan panjang badan yang sama dengan neonatus yang diberikan ASI non eksklusif. Hal ini dapat disebabkan oleh kandungan nutrisi ASI eksklusif berbeda dengan ASI non eksklusif. Beberapa zat gizi dalam ASI yang berguna untuk pertumbuhan tulang, diantaranya adalahprotein, mineral dan vitamin. Protein dalam ASI lebih rendah dibandingkan dengan ASI non eksklusif, misalnya susu formula. Namun demikian protein ASI sangat cocok karena unsur protein di dalamnya hampir seluruhnya terserap oleh sistem pencernaan bayi yaitu protein unsur whey. ${ }^{27}$ Pada akhirnya hal ini mempengaruhi pertambahan 
panjang badan pada bayi.

Kelompok neonatus yang diberikan ASI eksklusif dan ASI non eksklusif mencapai rata-rata panjang badan yang sama pada minggu keempat sebesar $3 \mathrm{~cm}$. Namun, kelompok neonates dengan pemberian ASI ekslusif mengalami peningkatan panjang badan yang lebih cepat pada hari ke-14 $(3,00 \mathrm{~cm})$, sedangkan perubahan panjang badan neonatus yang diberikan ASI non eksklusif lebih lambat yaitu pada hari ke-28 $(3,00 \mathrm{~cm})$. Penelitian kohort Boyd-Orr yang pertama kali mempelajari dampak jangka panjang dari pemberian ASI pada masa bayi terhadap panjang badan pada masa kanak-kanak dan dewasa, menunjukkan bahwa anak yang mendapat ASI pada masa bayinya secara bermakna lebih tinggi dibanding anak yang mendapat susu formula.

\section{KESIMPULAN DAN SARAN}

Berdasarkan penelitian yang dilakukan di RSUD Depati Hamzah Kota Pangkalpinang, maka dapat disimpulkan bahwa status pemberian ASI sebagian besar bayi neonatus diberikan ASI non eksklusif sebanyak 55,9\% (19 orang). Diketahui bahwa rata-rata perubahan panjang badan bayi neonatus lebih cepat meningkat pada kelompok bayi neonatus yang diberikan ASI eksklusif, yaitu pada hari ke-14 $(3,00 \mathrm{~cm})$.Ada perbedaan antara rata-rata perubahan panjang badan kelompok bayi neonatus yang diberikan ASI eksklusif dan kelompok bayi neonatus yang diberikan ASI non eksklusif dengan nilai $p<0,05$. Saran yang dapat diberikan berdasarkan hasil penelitian adalah bagi tenaga kesehatan di RSUD Depati Hamzah Kota Pangkalpinang, agar dapat melakukan IMD agar dapat meningkatkan pemberian ASI eksklusif pada bayi neonatus hingga usia 6 bulan. Selain itu, bagi ibu agar memberikan nutrisi terbaik yaitu ASI secara eksklusif bagi bayinya. Fatimah ${ }^{28}$ mengungkapkan bahwa untuk meningkatkan keberhasilan pemberian ASI eksklusif hendaknya mengurangi bahkan menghilangkan penggunaan susu formula ataupun cairan lainnya yang diberikan kepada bayi pada saat berumur 0-6 bulan. Dengan demikian diharapkan pemberian ASI ekssklusif kepada bayi dapat lebih optimal.

\section{DAFTAR PUSTAKA}

1. Sofyana, Haris. Perbedaan Dampak Pembe- rian Nutrisi ASI Eksklusif dan Non Eksklusif terhadap Perubahan Ukuran Antropometri dan Status Imunitas Pada Neonatus di Rumah Sakit Umum Daerah (RSUD) Al Ihsan Provinsi Jawa Barat [Tesis]. Depok : Fakultas Ilmu Keperawatan Depok; 2011.

2. Nanny Lia Dewi, Vivian. Asuhan Neonatus Bayi dan Anak Balita. Jakarta: Salemba Medika; 2010.

3. Fitri, D. I., Chundrayetti, E., dan Semiarty, R. Hubungan Pemberian ASI dengan Tumbuh Kembang Bayi Umur 6 Bulan di Puskesmas Nanggalo. Jurnal Kesehatan Andalas.136-140.

4. Ahmad, A., Suryana., dan Fitri, Y. ASI Eksklusif Anemia dan Stunting pada Anak Baduta (6-24 Bulan) di Kecamatan Darul Imarah Kabupaten Aceh Besar [Karya Tulis Ilmiah]. D.I.Y Aceh: Poltekkes Kemenkes Aceh; 2010

5. Susanty M, Kartika M, Hadju V dan Alharini S. Hubungan Pola Pemberian ASI dan MP ASI dengan Gizi Buruk pada Anak 6-24 Bulan di Kelurahan Pannampu Makassar. Media Gizi Masyarakat Indonesia. 2012;97-103.

6. UNICEF dan WHO. Advocacy Breastfeeding Advocacy Initiative For The Best Start In Life. UNICEF and World Health Organization. 2009 [Diakses 20 Agustus 2015]. Available at:http://www.unicef.org/publications.

7. Kementrian Kesehatan RI. Rencana Strategis Kementerian Kesehatan Tahun 2015-2019. Jakarta: Kementerian Kesehatan RI; 2015.

8. Kementrian Kesehatan RI.Profil Kesehatan Indonesia Tahun 2013. Jakarta: Kementerian Kesehatan RI; 2014.

9. Dinas Kesehatan Provinsi Kepulauan Bangka Belitung. Profil Kesehatan Provinsi Kepulauan Bangka Belitung 2013. Pangkalpinang: Dinas Kesehatan Provinsi Kepulauan Bangka Belitung; 2014.

10. Notoatmodjo, S. Metodologi Penelitian Kesehatan. Jakarta: Rineka Cipta; 2012.

11. Baskoro, Anton. ASI : Panduan Praktis Ibu Menyusui. Yogyakarta: Banyu Media; 2008.

12. Marimbi, H. Tumbuh Kembang, Status Gizi \& Imunisasi Dasar Pada Balita. Yogyakarta: Nuha Medika; 2010.

13. Mohrbacher, Nancy dan Tackett, K. K. Breastfeeding Made Simple: Seven Natural Laws for Nursing Mothers. Canada: New Harbinger 
Publication; 2005.

14. Hasianah, S.T., Ivone, J., dan Rentian, N. Pengaruh Sectio Caesarea Terhadap Keberhasilan ASI Eksklusif [Skripsi]. Bandung: Fakultas Kedokteran Universitas Kristen Maranatha; 2014.

15. Fikawati, S. Praktik Pemberian ASI Eksklusif, Penyebab-Penyebab Keberhasilan dan Kegagalannya. Jurnal Kesehatan Masyarakat Nasional.Tahun 2009;4(3):120-131.

16. Riksani, Ria. Keajaiban ASI (Air Susu Ibu). Jakarta: Dunia Sehat; 2012.

17. Juliastuti, R. Hubungan Tingkat Pengetahuan, Status Pekerjaan Ibu, dan Pelaksanaan Inisiasi Menyusui Dini dengan Pemberian ASI Eksklusif [Tesis]. Surakarta : Program Studi Magister Kedokteran Keluarga Minat Utama Pendidikan Profesor Kesehatan; 2011.

18. Supariasa, I. D. N., Bakri, B., dan Fajar, I. Penilaian Status Gizi. Jakarta: Buku Kedokteran EGC; 2012.

19. Khamzah, S. N. Segudang Keajaiban ASI Yang Harus Anda Ketahui. Yogyakarta: FlashBooks; 2012.

20. Susilaningrum R, Nursalam, Utami S. Asuhan Keperawatan Bayi dan Anak untuk Perawat dan Bidan. Jakarta: Salemba Medika; 2005.

21. Anugraheni H S, Kartasurya M I. Faktor Risiko Kejadian Stunting Pada Anak Usia 1236 Bulan di Kecamatan Pati, Kabupaten Pati. Journal of Nutrition College. 2012;1(1): 30-
37.

22. Rahayu L.S, Sofyaningsih M. Pengaruh BBLR (Berat Badan Lahir Rendah) dan Pemberian ASI Eksklusif Terhadap Perubahan Status Stunting Pada Balita di Kota dan Kabupaten Tangerang Provinsi Banten. Prosiding Seminar Nasional "Peran Kesehatan Masyarakat dalam Pencapaian MDG's di Indonesia"; 12 April 2011.

23. Ariani, A. Peningkatan Berat Badan pada Bayi Prematur yang Mendapat ASI, PASI, dan Kombinasi ASI - PASI. Majalah Kedokteran Nusantara. 2007; 81-85.

24. Susiloretni. The Effectiveness of Multilevel Promotion of Exclusive Breastfeeding in Rural Indonesia. American Journal Of Health Promotion. 2013:1-12.

25. Lony N, Gurnida DA, Garna H. Perbandingan Fungsi Kognitif Bayi Usia 6 Bulan yang Mendapat dan yang Tidak Mendapat ASI Eksklusif. Sari Pediatri. 2008; 429-434.

26. Amanda, G. Hubungan Lamanya Pemberian Asi dengan Status Gizi Anak Usia Kurang dari 2 Tahun di kecamatan Kartasura. Jurnal Penelitian Kesehatan 2011;5(4): 71-80.

27. Purwanti, H,S.,. Konsep Penerapan ASI Eksklusif. Jakarta: EGC; 2004.

28. Fatimah, et al. Breastfeeding in Malaysia: Results of The Third National Health and Morbidity Survey (NHMS III). Mal J Nutr. 195206. 